\title{
„INNY” JAKO WYTWÓR IMAGINACYJNEJ GEOGRAFII A GLOBALIZACJA
}

\begin{abstract}
This paper discusses creation of the image of the Other from the standpoint of globalization. The objective is to prove the thesis that due to its particular nature, global reality does not tolerate the dichotomy of us vs. them. Also, it is not invalidated by the awareness that one's own and the alien are more contiguous and permeate one another to a greater extent than ever before. The only elements which do change are the contexts surrounding that distinction and the tools of its production and dissemination. Within the consciousness, in the social notions and structures of knowledge, the post-colonial era remains profoundly colonial.
\end{abstract}

\section{Key words}

us-them dichotomy, the Other, imaginative geographies, myth, colonialism, imperialism, globalization 


\title{
WSTĘP
}

\author{
Ludzie idą na wojnę z powodu sposobu, \\ w jaki widzą, postrzegają, obrazują, \\ wyobrażają sobie i mówią o innych. \\ James Der Derian
}

Żyjemy w obiektywnej geograficznej przestrzeni, niemniej jednak tym, co ją określa, co nadaje jej wartość, przyznaje lub odbiera znaczenie, jest nasze o niej wyobrażenie. Edward Said nazwał je mianem ,imaginacyjnych geografii" $^{1}$ - kulturowych reprezentacji przestrzeni, które nigdy nie pozostają neutralne czy niewinne. Przeciwnie, nadają one realny kształt, treść i kierunek naszym działaniom. Zarówno imperializm, jak i kolonializm wyrastają na gruncie tego rodzaju wyobrażeń, w których przeświadczenie, że „jesteśmy «my» $\mathrm{i}$ «oni», jasno określeni i trwali i niepowtarzalnie odmienni”", staje się dlań kluczowe. Rozróżnienie na „my” i „oni” zwykle wiąże się z jakąś formą dominacji lub dążenia do jej osiągnięcia. „Ześrodkowanie na własnym ma swoje źródło w popędzie do samozachowania i samoekspansji. Ten, kto nie należy do naszej (...) grupy, ten jawi się jako ekonomiczny konkurent, polityczny przeciwnik i jako zagrożenie dla światowej kultury"3 - podkreśla Bernhard Waldenfels. Wyjście na zewnątrz, poza to, co „nasze”, na ogół nie oznacza przejścia na stronę Innego ${ }^{4}$. Do tej pory Inny stawał się albo wrogiem, albo polem do wchłonięcia, zawłaszczenia, uczynienia go „naszym” - oswojonym i bezpiecznym. Innymi słowy, podlegał procesowi asymilacji - „pożarciu”, antropofagii lub antropoemii - „wymiotowano” nim ${ }^{5}$, marginalizowano, odzierano z odmienności. Imaginacyjne geografie to produkty mitologizowania społecznej rzeczywistości - część imperialistycznego mitu. Pozwalają one nie tylko porządkować rzeczywistość, lecz również nadawać znaczenie niektórym jej elementom lub tworzącym ją podmiotom. Mogą także działać odwrotnie - destruować. Rozróżnienie na „my” i „oni” konstytuuje każdą formę dominacji, zmienia się jedynie towarzyszący jej kontekst. Celem artykułu jest wykazanie, że dychotomii tej nie unieważnia ani proces

\footnotetext{
${ }^{1}$ Said 1991.

${ }^{2}$ Said 2009, s. XXIV.

${ }^{3}$ Waldenfels 2002, s. 162 .

${ }^{4}$ Mówiąc o obcości, będę łączyć ją ściśle z pojęciem identyfikacji w sensie kolektywnym, za obce uznając „to, co wykluczone (...) z kolektywnej sfery własnego i oddzielone od kolektywnej egzystencji, czego więc nie dzieli się z innymi. Obcość w tym znaczeniu oznacza brak przynależności do pewnego «my»". Waldenfels 2002, s. 18.

${ }^{5}$ Bauman 2011.
} 
globalizacji, ani świadomość, że własne i obce styka się, przenika, przeplata bardziej niż kiedykolwiek. Globalizacja zmienia zaledwie mechanizmy wcielania i kreowania zależności.

\section{„IMAGINACYJNE GEOGRAFIE” NA USŁUGACH IMPERIALISTYCZNEGO MITU}

Dychotomia my-oni to jeden ze schematów mapowania rzeczywistości społecznej, na podstawie którego porządkujemy i czynimy - wydawać by się mogło - bardziej zrozumiałym wieloaspektowy charakter ludzkiego świata, w którym funkcjonujemy. Tymczasem za jej pomocą mitologizujemy rzeczywistość społeczną, potwierdzając Cassirerowską tezę o irracjonalnym do niej stosunku. Upraszczamy to, co złożone, stereotypizujemy, pozbywamy się wątpliwości, nadając światu pozorną przejrzystość. Z mitem, jak wskazuje Stanisław Filipowicz, „mamy do czynienia tam gdzie słowa mają status rzeczy, inspirują (...) działania, które stanowią ich dokładne urzeczywistnie-

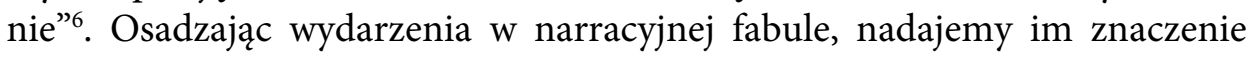
i pobudzamy do określonych działań. Za pomocą mitów, zwłaszcza politycznych, osiągamy cele, inscenizujemy historię, manipulujemy opinią publiczną.

Imaginacyjne geografie wiążą się z praktyką oznaczania $\mathrm{w}$ świadomości przestrzeni jako oswojonej, tj. „naszej”, oraz nieznanej, istniejącej poza „naszą" - przestrzeni „ich” " Jako takie stanowią one element wspólny wszystkich postaci imperializmu i kolonializmu. Granice wyznaczone w umysłach, gdzie " "oni» stają się «nimi», a ich terytorium i ich mentalność są traktowane jako różne od «naszych»", gdzie „nieoswojoną przestrzeń poza naszymi granicami zapełniają wszelkiego rodzaju dowolne założenia, skojarzenia i fikcje" ${ }^{8}$, stają się nie mniej realne niż granice geograficzne. Wyobraźnia i idące za nią słowo kreślą je równie skutecznie jak poziomice naniesione na mapę. Jak wyraził to John Armstrong, słowa pełnią funkcję ulicznej sygnalizacji, ostrzegają, gdy

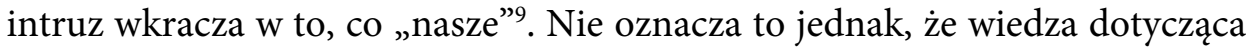
historii i geografii jest wyłącznie wytworem naszej, mniej lub bardziej świadomej, kreacji. Niemniej jednak trudno nie przyznać racji Ernestowi Cassirerowi, uznającemu rzeczywistość społeczną za szczególnie podatną na występowanie

\footnotetext{
${ }^{6}$ Filipowicz 1988, s. 48.

${ }^{7}$ Said 1991, s. 94.

${ }^{8}$ Ibidem

${ }^{9}$ Armstrong 1982, s. 7-8.
} 
irracjonalnych zjawisk i procesó $w^{10}$. Na podstawie tego rodzaju imaginacyjnej „wiedzy” tworzymy mity, opowieści zaspokajające potrzebę poczucia sensu, ładu i znaczenia. Taka wiedza była również kluczowym narzędziem w procesie kolonizacji, organizowania świata, porządkowania tych miejsc, gdzie w oczach kolonizatora panował bałagan, chaos nieprzystający do jego wyobrażeń ${ }^{11}$. Potwierdza to tezę wysuniętą prze Chiarę Bottici, zgodnie z jej sposobem myślenia, mit nie tyle opisuje rzeczywistość, co ją projektuje. $\mathrm{Z}$ tego powodu „prawda i fałsz nie są kryterium, wedle których (...) [mity - dop. J. B-P.] powinny być oceniane"12. Filipowicz komentuje to następująco:

Mit ma inny status niż prawdy teoretyczne. Wyraża pragnienia, których rozum nie kontroluje. Prawda mitu, prawda zobrazowana, działająca na emocje, zapada głęboko, nie jest podatna na żadne formy intelektualnej perswazji. Mitom politycznym nie zagraża nic tak długo, jak długo nie stracą znaczenia marzenia o doskonałości. Mitu nie można podważyć za pomocą żadnego rozumowania, ponieważ żadne rozumowanie go nie uzasadnia ${ }^{13}$.

Usunięcie mitów poza kryterium prawdy i fałszu nie eliminuje, rzecz jasna, praktycznych skutków, jakie ze sobą niosą. Przybierając polityczny charakter, niejednokrotnie stawały się wyrazem dominacji, opresji, pożywką dla politycznej, ekonomicznej i kulturowej przemocy. Imperialne i kolonialne praktyki potwierdzają, jak istotną rolę może odgrywać mit, stając się perspektywą, w jakiej ludzie postrzegają świat, działają w nim i go odczuwają.

Dychotomia my-oni, jako jeden z komponentów mitu, jest również wyrazem potrzeby skutecznego dowartościowania egzystencji. „Identyfikacja ze wzorem stanowi źródło głębokiej satysfakcji, stwarza poczucie pewności, umożliwia zaspokojenie głodu wielkości”14 - wskazywał Filipowicz. Francis Fukuyama fundamentem polityki czyni pragnienie, żądzę uznania, która domaga się potwierdzenia swojej godności i statusu ze strony innych osób ${ }^{15}$. W takim znaczeniu imperializm, będący wyrazem dominacji i jednocześnie świadectwem funkcjonującego podziału, może łączyć się $\mathrm{z}$ ofensywnym wariantem etnocentryzmu (który Waldenfels wiąże $\mathrm{z}$ nacjonalizmem) ukierun-

\footnotetext{
${ }^{10}$ Biernat 1988, s. 59.

${ }^{11}$ Dychotomia my-oni wpisuje się m.in. w polityczną postać mitu, stanowiła bowiem odwołanie i uzasadnienie świadomej polityki kolonizatora zaangażowanej w ekspansję i rozwój kolonii realizowanych w oparciu o polityczną zależność od metropolii obszarów nieposiadających niepodległości.

${ }^{12}$ Bottici 2011, s. 39. Zdaniem Bottici tego rodzaju tendencja jest ugruntowana w pozytywistycznym spojrzeniu na język, który opisując wyłącznie fakty, rości sobie prawo do prawdy.

${ }^{13}$ Filipowicz 1988, s. 80.

${ }^{14}$ Ibidem, s. 59.

${ }^{15}$ Zob. Fukuyama 1996, s. 200-202, 211-220, 222, 250.
} 
kowanym na ekspansję, podbój, wcielenie. W przeciwieństwie do wariantu defensywnego, wyrażającego się w postawie obronnej, gdzie - jak ujął to Waldenfels - „świat jest tam, gdzie człowiek jest u siebie w domu”"16, w jego ofensywnej postaci „człowiek czuje się w świecie jak u siebie w domu” ${ }^{17}$. Źródłem legitymizacji porządkowania świata stają się wspomniane imaginacyjne geografie, mity dające mu złudne wrażenie panowania nad rzeczywistością, a przede wszystkim poczucie znaczenia.

Pojęcie „imaginacyjnych geografii” stało się jednym z kluczowych w studiach postkolonialnych, niemniej jednak tego rodzaju mityczne wyobrażenia towarzyszą nie tylko różnym postaciom kolonializmu czy imperializmu, są one immanentne każdej formie dominacji, nie przestały zatem mieć znaczenia również w rzeczywistości globalnej. Jeśli uznamy wyobrażenie Innego za zasadniczy punkt odwołania dla imperialnych czy kolonialnych praktyk, warto się zastanowić, czy w ogóle, a jeśli tak, to na ile postkolonializm i globalizacja zmieniają ów ogląd, a co za tym idzie, czy w istotnym sensie redefiniują sam obraz Innego. „Geografia nierozerwalnie związana jest $\mathrm{z}$ architekturą wrogości”18 - pisał Michael Shapiro, czy zatem globalizacja w jakiś zasadniczy sposób zmienia to przekonanie? Czy przewartościowuje obraz Innego?, a jeśli tak, czy nadal pozostaje on w opozycji? Czy być może staje się kimś podobnym do „nas”, a może kimś „pomiędzy” „my” a „oni”?

Jeśli przyjmując, za Bottici, iż jedną z charakterystycznych cech mitu jest to, że nie ma on ostatecznej postaci, a praca nad nim to ustawiczny proces opracowywania narracji odpowiadającej na zmieniające się potrzeby i znaczenia $^{19}$, wówczas - po pierwsze - geografia staje się jedynie incydentalnym, tymczasowym wyznacznikiem Innego, przestaje mieć znaczenie w globalnej rzeczywistości. Po drugie, postkolonializm, przepełniony echem kolonialnych praktyk, nie usuwa konstytuującej go dychotomii. Wprawdzie ten binarny układ, na którym wyrosła kolonialno-imperialna dominacja, został podważony przez postkolonialną debatę, gdzie tożsamość kulturowa skolonizowanego przestaje być postrzegana jako bierna kopia tożsamości kolonizatora; gdzie obie tożsamości pozostają w nieustannej interakcji, nie został jednak zniesiony. Dychotomia my-oni pozostaje w nieustannym procesie przekształcania, nakładania na nią coraz to nowych znaczeń i użytecznych narracji. Nie zniknęła, w zależności od potrzeb zmienia jedynie swoje „przebrania”.

\footnotetext{
${ }^{16}$ Waldenfels 2002, s. 163.

${ }^{17}$ Ibidem.

${ }^{18}$ Cyt. za: Gregory 2004, s. 20.

${ }^{19}$ Bottici 2011, s. 36.
} 
Jak wskazuje Waldenfels, starożytne rozróżnienia na Greków i barbarzyńców ulegało redukcji w miarę jak obcy zbliżał się do rozumu. Dzisiaj różnica między tym, co „nasze” a tym, co „obce” zmienia swój charakter z wertykalnego, ściśle wyznaczonego i określonego porządku, na horyzontalny - rozproszony, przesunięty $z$ centrum na peryferie ${ }^{20}$. Odkrycia geograficzne i związane z nimi zdobycze uświadamiają nam, że:

\begin{abstract}
obce jawnie i nieodwołalnie przenika do samego jądra rozumu i samego jądra tego, co własne. Wyzwanie, jakim jest dla nas to, co radykalnie obce, oznacza, że nie istnieje świat, $\mathrm{w}$ którym bylibyśmy w pełni u siebie, i że nie istnieje podmiot, który byłby panem we własnym domu ${ }^{21}$.
\end{abstract}

To w tym miejscu Homi K. Bhabha ${ }^{22}$ dostrzega przestrzeń, która oddaje głos Innym - tym, którym odmawia go Gayatri Chakravorty Spivak ${ }^{23}$. „Trzecia przestrzeń”, jak określa ją Bhabha, tworzy zupełnie nową możliwość reprezentacji, a co z tym związane, również obrazu Innego. Żadna ze stron tego układu nie pozostaje bierna, a dychotomia my-oni staje się mniej przejrzysta. Nie oznacza to jednak, że zostaje zniesiona.

Szeroka debata nad imperializmem, kolonializmem i Orientalizmem obudziła świadomość interakcji zachodzącej między Zachodem a Orientem, ich wzajemnego przenikania, obustronnej zależności i narracji. Za Saidem Derek Gregory większość narracji dotyczących Zachodu uznaje za samoprodukcje wywołujące jego ślepotę; mity samowystarczalności, w których Zachód przynosi Innemu owoce postępu, będące, w innym przypadku, poza jego zasięgiem. Zachodnia projekcja jest silnie związana i zdeterminowana przez opozycję, w stosunku do której się kształtuje. Odbywa się to, jak wskazuje Gregory, w złamanym i nierównym polu sił, gdzie kultury sprzęgają się i wywierają na siebie nacisk. Proces kolonialnej transkulturacji jest jednak z natury asymetryczny. Gregory mówi o wewnętrznie kolonialnej nowoczesności, która za pomocą odpowiedniej narracji produkuje swojego Innego i jednocześnie kreuje swoją uprzywilejowaną pozycję. Świadczy to o nadzwyczajnej sile i performatywnej mocy kolonialnej nowoczesności. Konstruuje ona inne kultury w sposób, w jaki są rozumiane w bezpośrednim sensie, ale także w sposób, w jaki wytwarzane są ich mniej lub bardziej trwałe kodyfikacje - predyspozycje i rozmieszczenia ${ }^{24}$. Wskazana asymetryczność nie tylko zasadza się na dychotomii my-oni, ale również ją podtrzymuje i wzmacnia.

${ }^{20}$ Waldenfels 2002, s. 11-12.

${ }^{21}$ Ibidem, s. 12.

${ }^{22}$ Bhabha 2009.

${ }^{23}$ Spivak 2011, s. 196-239.

${ }^{24}$ Gregory 2004, s. 4. 


\section{PRZESTRZEŃ, KULTURA, TOŻSAMOŚĆ, „INNY” W PROCESIE GLOBALIZACJI}

Rozróżnienie na „my” i „oni”, na którym wzrastały zarówno kolonializm, jak i imperializm, wzmacniały ściśle wyznaczone geograficzne granice. W ślad za nim zrodził się podział na imperialną metropolię i kolonialne peryferia wyznaczający równie przejrzyste wzory dominacji i marginalizacji. Globalizacja zamazuje dychotomię ja-Inny stanowiącą podstawę i jednocześnie legitymizację kolonialnej i imperialnej podmiotowości. Czy jednak "uświatowienie" Innego w jakiś zasadniczy sposób znosi jego peryferyjność, a tym samym zmienia nasze o nim wyobrażenie? Kim staje się dzisiejszy Inny, ten, który niegdyś umacniał poczucie zachodniej tożsamości, określając różnice między tym, co bliskie, a tym, co dalekie?

Jak wspomniano, za sprawą globalizacji opozycja centrum-peryferie rozmywa się. Obecnie mamy do czynienia z sytuacją, w której, jak ujmuje to Waldenfels, „rozróżnieniu na własne i obce odpowiada raczej pewna sieć, «splot», w którym własne i obce przeplatają się; są tam punkty węzłowe i połączenia poprzeczne, ale brak centrum. (...) Na ruinach «porządku piramidalnego» mogłaby wyrosnąć lateralna forma ogólności, nie ukierunkowana na jednolitą, wertykalną ogólność od góry, lecz rozprzestrzeniająca się wszerz"25. Czy zatem globalizacja sprawiła, że geografia - wszak kluczowa dla kolonializmu - przestała mieć znaczenie w identyfikacji Obcego? Nie znaleźliśmy się nagle ponad geografią, niemniej jednak państwowe granice przestają odgrywać w tym procesie zasadniczą rolę. Nie potrzebujemy już granic (nie potrzebuje ich imperializm), by określone formy, reprezentacje i wyobrażenia zaistniały w odległym zakątku globu. Dzisiaj ich przenikanie nie wymaga dział i żołnierzy. Odeszliśmy od praktyki terytorialnych podbojów, bezpośredni kontakt, aneksja przestały być konieczne w procesie okupacji umysłów i kultury. Teraz odbywa się to za sprawą globalizacji, na dużo większą skalę i bez stosowania jawnej przemocy. Aktualne pozostało więc to, co konstytutywne dla każdej historycznej postaci kolonializmu, a mianowicie mesjanistyczny charakter, w którym dzisiejszy posłaniec - cywilizowany świat - nieprzerwanie wieszczy racjonalizm, modernizację i liberalizm barbarzyńskiemu światu ${ }^{26}$ - „próbuje systemowo przekształcić bądź zanegować kulturową różnicę i wartość «nie-Zachodu»"27. Odejście od siłowych metod

\footnotetext{
${ }^{25}$ Ibidem, s. 151.

${ }^{26}$ Cyt. za: Gandhi 2008, s. 22.

${ }^{27}$ Ibidem, s. 23.
} 
poszerzania granic nie wyeliminowało dominacji i zależności. Przestrzeń nie jest już tak atrakcyjna jak kiedyś, gdyż w zglobalizowanej rzeczywistości przestała być konieczna do uzyskania dominacji, władzy czy bogactwa.

Globalizacja wymusza nie tylko odmienne spojrzenie na relację z Innym - innymi kulturami, państwami, doświadczeniami, zasadniczo podważa kolonialną perspektywę oglądu rzeczywistości, jednak nie znosi Innego. Globalizacja jedynie redefiniuje jego wyobrażenie jako ściśle związane z miejscem, z jednolitą przestrzenią. Niegdyś kolonizator fizycznie wkraczał w przestrzeń Obcego przeświadczony o konieczności uczynienia jej swoją. Paradoksalnie, skutkiem imperialistycznej ekspansji i związanego z nią kolonializmu stała się globalizacja, która uchyla pierwotną, tj. geograficznie zakreśloną, dychotomię będącą podstawą ich istnienia. W postkolonialnym świecie to niedawny kolonizowany wchodzi w przestrzeń kolonizatora, starając się znaleźć w niej własne miejsce. „My” i „oni” egzystujemy w jednej przestrzeni lub kilku wspólnych przestrzeniach. Inny, jak wskazują Michael Hardt i Antonio Negri:

\begin{abstract}
wkracza do Pierwszego Świata, osadza się w jego sercu jako getto, slums, favela, nieustannie produkowane i reprodukowane. Z kolei Pierwszy Swiat przepływa do Trzeciego w postaci giełd i banków, ponadnarodowych korporacji oraz niebotycznych stosów pieniędzy i rozkazów. Geografia gospodarcza i polityczna ulegają rozchwianiu w tym sensie, że granice między poszczególnymi sferami stają się płynne i ruchome ${ }^{28}$.
\end{abstract}

Identyfikacja Obcego nie musi już następować poprzez rozgraniczenie tego, co położone na własnym obszarze, od tego, co poza nim. Peryferyjność Innego nie implikuje jego geograficznego oddalenia, a to z kolei - zasadniczej zmiany jego obrazu. Inny stoi bliżej niż kiedykolwiek, jednak wyobrażenie o nim pozostaje zakorzenione w odległej kolonialnej przeszłości.

Nowa globalna rzeczywistość wymusiła zupełnie inne spojrzenie na dawne idee, podziały utrwalone w imperialnej świadomości. Trzy niegdyś ściśle zespolone kategorie: miejsce, kultura, tożsamość, w oparciu o które budowano wyobrażenie Innego, ulegają rozproszeniu. W rezultacie tego Inny nie jest już dokładnie zlokalizowany czy zakorzeniony w przestrzeni - staje się częścią naszej przestrzeni, współtworzy kulturę, jest mniej rozpoznawalny. Co zatem w epoce globalizacji oddziela "nasze” od „nie-naszego”, wyznacza - wydawać by się mogło - względnie bezpieczne pole odcinające od tego, co nieznane, co na zewnątrz? Skoro przestrzenne granice zacierają się, czy pozostały jeszcze inne, mające nadal znaczenie $\mathrm{w}$ procesie określania tożsamości, osiągania dominacji i wykluczania? Said podkreśla, że tym, co różni dominację Ameryki

\footnotetext{
${ }^{28}$ Hardt i Negri 2005, s. 274.
} 
od klasycznej hegemonii imperialistycznej, jest bezprecedensowy zasięg autorytetu kulturowego. Globalizacja przekazu, a przede wszystkim kontrola informacji, sprawiły, że fizyczna obecność kolonizatora przestała być kluczowa, dziś jego miejsce zajęły media o globalnym zasięgu. Tak oto mamy do czynienia z nowym mechanizmem wcielania i kreowania zależności ${ }^{29}$.

Niezależenie od tego, w jaki sposób określimy współczesną formę dominacji, mianem „imperializmu” czy „kolonializmu”30, np. kolonializmu cywilizującego ${ }^{31}$, jej istota sprowadza się do relacji między kulturą a władzą. W studiach postkolonialnych kultura nie jest traktowana jako tło czy lustro rzekomo bardziej podstawowych struktur jak geografia, polityczno-ekonomiczne siły czy militarna przemoc. Kultura obejmuje produkcję, obieg i legitymizację znaczeń poprzez reprezentacje i praktyki, które w pełni wchodzą w skład konstytucji rzeczywistości ${ }^{32}$. Dzisiaj zasadniczym polem jej oddziaływania stały się wspomniane media. Jak wskazuje Said:

\begin{abstract}
Zagrożenie dla niepodległości, jakie pod koniec XX wieku stwarza nowa elektronika, może się okazać większe niż sam kolonializm. Zaczynamy odkrywać, że dekolonizacja i pojawienie się ponadnacjonalizmu nie przyniosły zakończenia relacji imperialistycznych, lecz były zaledwie rozszerzeniem geopolitycznej sieci, plecionej od czasów renesansu. Nowe media mają moc przenikania głębiej w „przyjmującą” kulturę niż wszelkie inne wcześniejsze przejawy zachodniej technologii ${ }^{33}$.
\end{abstract}

Wbrew głoszonej przez Hardta i Negri tezie o upadku dialektyki kolonializmu - skolonizowanego, wytworzonego jako Inny, ten, który przez wieki był podstawą Ja - europejskiej tożsamości; dobroci, ucywilizowania i przyzwoitości kolonizatora $^{34}$, jak również samego kolonizatora, okazuje się, że świadomość symplifikacji binarnego schematu my-oni, osłabianego przez geopolityczno-kulturową sieć różnorodnych podziałów społecznych, nie usuwa go w pełni. Obraz Innego jako twór imaginacyjnych geografii nadal stanowi przedmiot odwołania retoryki usprawiedliwiającej i wartościującej

${ }^{29}$ Said 2009, s. 333-334.

${ }^{30}$ Współczesny zachodni imperializm stanowi dziedzictwo kolonializmu. Trudno o wyraźne rozgraniczenie między terminami „kolonializm” a „imperializm”, często są one używane zamiennie i w dość swobodny sposób. Można byłoby zastanowić się, na ile jest to rezultatem ignorancji, a na ile historycznych konotacji, jakie między nimi powstały. Jasne kryterium, umożliwiające nakreślenie semantycznych granic obu pojęć, z pewnością przyczyniłoby się do bardziej rzetelnej analizy współczesnych zjawisk społecznych.

${ }^{31}$ Ashis Nandy mówi o współczesnym kolonializmie, określając go mianem „cywilizującego” (w przeciwieństwie do militarystycznego). Jego celem nie jest terytorialny podbój, a zdobycie i okupacja umysłów, kultury. Cyt. za: Gandhi 2008, s. 22.

${ }^{32}$ Gregory 2004, s. 8

${ }^{33}$ Said 2009, s. 333-334.

${ }^{34}$ Hardt i Negri 2005, s. 143. 
nasze działania ${ }^{35}$. Jak twierdzi Gregory, współczesny kolonializm jest kształtowany nie tylko przez geopolitykę i geoekonomię, lecz również kulturowe formy i praktyki, które naznaczają innych ludzi jako nieodwracalnie Innych, Obcych, legitymizując stosowanie wobec nich przemocy. Konstelacje siły, wiedzy i geografii wciąż kolonizują świat. Współcześnie skolonizowanie nie ogranicza się do emisariuszy starych lub nowych imperiów, formalnych czy nieformalnych, sprowadza się raczej do kwestii rozpoznania sposobów, $\mathrm{w}$ jakich myślenie i działanie wielu $\mathrm{z}$ nas pozostaje „zabarwione kolonialną siłą" ${ }^{36}$. Za najbardziej fundamentalny problem, przed jakim stoimy w pierwszych dziesięcioleciach XXI wieku, Boaventura de Sousa Santos uznaje ignorowanie, niedostrzeganie trwałości linii oddzielającej metropolie od społeczeństw kolonialnych. Jego zdaniem jest ona na tyle głęboka, że wszystko, co znajduje się po jej drugiej stronie, pozostaje niewidoczne, a co za tym idzie - zupełnie nieistotne. Santos określa ją mianem „linii otchłani”. To linia kreślona w ludzkich umysłach, nie sposób jej zobaczyć i z tego powodu pozostaje najtrudniejsza i być może niemożliwa do przekroczenia ${ }^{37}$. Stanowi ona echo kolonializmu, przekonania o kulturowej dominacji, o uniwersalizmie wartości, a w konsekwencji nadal prowadzi do represji, wyzysku, poczucia imperialnej wyższości. Specyfika globalnej rzeczywistości nie wyeliminowała właściwych postkolonialnemu dyskursowi opozycji (dominacja-zależność, rozwój-niedorozwój, cywilizacja-barbarzyństwo), a co za tym idzie, nie zniosła dychotomii my-oni. Za jej sprawą stały się one jedynie geograficznie niedomknięte, wymykają się przestrzennej identyfikacji.

\section{PODSUMOWANIE}

Mitologiczny kapitał stanowił fundament ustanawiania kolonialnej dominacji. Jednak imaginacyjne geografie $\mathrm{w}$ dalszym ciągu porządkują społeczną rzeczywistość. Polityczna mitologia dostarcza symboli, obrazów i mitów nie tylko celem zaprowadzenia i utrzymania ładu czy potwierdzenia znaczenia

${ }^{35} \mathrm{Za}$ znamienny przykład posłużyć może tzw. wojna $\mathrm{z}$ terroryzmem oraz inwazja na Irak. U podstaw moralnej i prawnej legitymizacji podejmowanych działań legła metanarracja przywołująca jakoby wciąż trwającą walkę między cywilizacją a barbarzyństwem. Według Richarda Jacksona język, w którym nowi barbarzyńcy - terroryści - przyrównani zostają do zwierząt, jest kontynuacją kolonialnych postaw, społecznego darwinizmu dzielącego świat na niższe i wyższe rasy ludzkie. Uznaje go za akt nie tylko kreowania tożsamości dzięki rozróżnieniu na cywilizowanych „nas” i barbarzyńskich „ich”, lecz również dehumanizacji i demonizacji Innego. Szerzej zob.: Jackson 2005.

${ }^{36}$ Gregory 2004, s. 16, xv.

${ }^{37}$ Santos 2014, s. 26, 106. 
będącego - jak twierdzi Hans Blumenberg - formą obrony przed obojętnością świata, którą mit zwalcza poprzez osadzanie wydarzeń w narracyjnej fabule $^{38}$. Ponadto dzisiaj mit również wypełnia aksjologiczną pustkę. Obecna w politycznej mitologii dychotomia my-oni jest jedną ze składowych tego, co Fredrik Barth określa mianem „transakcyjnych granic” chroniących przed konfrontacją z innymi kulturami, a tym samym przed zmianą, przekształceniem $^{39}$. Dychotomia my-oni stanowi narzędzie mitologizowania rzeczywistość społecznej, na tyle silne, że granice wyznaczone w umysłach stają się równie realne jak granice geograficzne. Jako taka stanowi ona jeden $\mathrm{z}$ elementów konstytuujących wiele mitów ( $\mathrm{w}$ tym mit narodu, mit imperialny) stale obecnych w kulturze. Jak wykazano, dziś zmieniają się jedynie narzędzia produkcji i dyslokacji mitu, dzięki którym zyskuje on jeszcze większą siłę oddziaływania.

Dychotomia my-oni nie stanowi, rzecz jasna, odrębnego mitu. Jest raczej elementem, konceptem, którym posługujemy się w procesie opracowywania narracji mitu, zapewniającej znaczenie w konkretnych politycznych warunkach oraz działaniach określonych grup społecznych. Dychotomia my-oni to przykład performatywnej mocy języka, tego, jak za pomocą wyobrażeń, imaginacyjnych geografii, słowa tworzona jest rzeczywistość. Jak trafnie ujmuje to Bottici: mity „nie mają na celu «opisać» (...), ale raczej (...) «tworzyć» swój własny świat. Parafrazując Wittgensteina, są samospełniające się"40. Mit polityczny oddziałuje obosiecznie, z jednej strony konsoliduje, inspiruje, motywuje, $\mathrm{z}$ drugiej - staje się narzędziem manipulacji społeczną świadomością. Jest punktem odniesienia $\mathrm{w}$ budowaniu poczucia bezpieczeństwa, ale w równym stopniu może je podważać. „Ten sam mit polityczny może być źródłem zarówno opresji, jak i wyzwolenia - w zależności od kontekstu"41.

Dziś kontekst ten zmienia się za sprawą globalizacji. Globalizacja sprawia, że geografia staje się jedynie incydentalnym wyznacznikiem Innego. Przestrzeń przestaje mieć znaczenie w uzyskiwaniu dominacji, władzy i bogactwa. Określone formy, reprezentacje i wyobrażenia zostają przeniesione w odległe zakątki globu za pomocą zupełnie innych narzędzi - mediów o globalnym zasięgu. Taka forma okupacji umysłów i kultury odbywa się na bezprecedensową skalę, więcej, unika stosowania jawnej przemocy. Tworzy zupełnie nowy

\footnotetext{
${ }^{38}$ Cytat. za: Bottici 2011, s. 38.

${ }^{39}$ Barth 2006, s. 355.

${ }^{40}$ Ibidem, s. 34.

${ }^{41}$ Bottici 2011, s. 35.
} 
mechanizm wcielania i kreowania zależności. Okazuje się, że dzisiaj skolonizowanie w zasadniczej mierze sprowadza się do kwestii rozpoznania sposobów, $\mathrm{w}$ jakich myślenie i działanie wielu $\mathrm{z}$ nas pozostaje „zabarwione kolonialną siłą”. W tym procesie imaginacyjne geografie mają nadal zasadnicze znaczenie. Inny stoi bliżej niż kiedykolwiek, jednak wyobrażenie o nim pozostaje głęboko zakorzenione w odległej kolonialnej przeszłości. Imaginacyjne geografie sprawiają, że epoka postkolonialna, nawet jeśli usuniemy z niej polityczne i ekonomicznej praktyki kolonialne, nadal w świadomości, w społecznych wyobrażeniach i w strukturach wiedzy pozostaje trwale kolonialna - naznaczona znamieniem, które można próbować zacierać, ale nigdy w pełni usunąć.

\section{“THE OTHER" AS A CREATION OF IMAGINATIVE GEOGRAPHIES VS. GLOBALIZATION}

\section{Summary}

The paper discusses creation of the image of the Other from the standpoint of globalization. The goal here is to prove the thesis that due to its particular nature, global reality does not tolerate the dichotomy of us vs. them. The latter proves to be a constitutive element of each domination, while the only elements which do change are the contexts surrounding that distinction and the tools which serve to produce and disseminate it. The key notion in these deliberations are "imaginative geographies", which arise from the practice of mentally demarcating space into "our" and "their" domains. It is through reference to such imaginative knowledge that we forge myths, tales that satisfy the need for things to make sense, possess an order and harbour meaning - thus we design reality. Imaginative geographies have by no means lost their significance in the global reality. The us - them dichotomy remains equally relevant; it is merely superimposed with new meanings and useful narratives.

\section{Bibliografia}

Armstrong J. 1982, Nations before Nationalism, Chapel Hill.

Barth F. 2006, Grupy i granice etniczne: społeczna organizacja różnic kulturowych, [w:] Badanie kultury. Elementy teorii antropologicznej. Kontynuacje, Warszawa.

Bauman Z. 2011, Kultura w płynnej nowoczesności, Warszawa, 348-377.

Bhabha H.K. 2009, Miejsca kultury, Kraków.

Biernat T. 1988, Mit polityczny, Warszawa.

Bottici Ch. 2011, Towards a Philosophy of Political Myth, European Journal of Philosophy and Public Debate, III 5 April, s. 31-52.

Filipowicz S. 1988, Mit i spektakl władzy, Warszawa. 
Fukuyama F. 1996, Koniec historii, Poznań.

Gandhi L. 2004, Teoria postkolonialna. Wprowadzenie krytyczne, Poznań.

Gregory D. 2004, The Colonial Present: Afghanistan, Palestine, Iraq, Malden.

Hardt M. i Negri A. 2005, Imperium, Warszawa.

Jackson R. 2005, Writing the War on Terrorism. Language, Politics and Counter-terrorism, Manchester-New York.

Said E. 1991, Orientalizm, Warszawa.

Said E. 2009, Kultura i imperializm, Kraków.

Santos B. 2014, Epistemologies of the South, Justice Against Epistemicide, Londyn.

Spivak G.Ch. 2011, Czy podporządkowani inni mogą przemówić?, Krytyka Polityczna, 24-25, s. 196-239.

Waldenfels B. 2002, Typografia obcego, Warszawa. 